and snows falls in winter. Compositæ abound. Of nearly 1000 species that have been collected in this region, $6 \mathrm{I}$ genera and $23 \mathrm{I}$ species are referable to this Order. Of Orchids only four species have been found Rutaceæ, Ericaceæ, and Restiaceæ are all but absent, and Proteaceæ wholly so.

(5) The Kalahari Region is the name Mr. Bolus gives to the vast tract of country north of the Composite region, west of the Natal region, and south of the tropic of Capricorn. It is a desert country, with an extreme climate, a rainfall of summer thunderstorms, hot summers with cool nights, and frosts in winter. Its essential features are of a country clothed with grass in tufts, and isolated shrubs and trees, which form forests in the north, and are thus probably continuous with the forests of tropical Africa. The Cape flora has here disappeared, and with it we take leave of Mr. Bolus's very able and most interesting contribution to botanical geography, regretting that want of space prevents any notice being taken of the many valuable observations and comparisons that he has made relating to the affinities of the South African with the Australian flora, and other matters of scientific interest.

J. D. H.

\section{THE INTERNATIONAL COMMITTEE OF WEIGHTS AND MEASURES}

THE Comité International des Poids et Mesures, which 1 has its bureau at Sèvres, has recently issued its ninth Report to the contracting Governments. The Report gives an account of the work done by the Committee during $\mathbf{1 8 8 5}$, and a statement of the probable expenses of the Committee for the current year. During the last year new instruments for the accurate comparison of standards of the metric system have been obtained at a cost of about 500/., making a total cost of about $7000 l$. for instruments supplied to the Bureau. For the present year the expenses of the Bureau are estimated at 100,000 francs (4000l.), the annual expenditure of the Committee being limited by the Convention to that amount, of which sum about $265 \%$. is for payments to various officers of the Comite. These expenses are divided amongst the twenty contracting Governments, the annual contribution of Great Britain and Ireland amounting to about jool. The new instruments include a comparator for measures of length by $M$. Brunner; new mercurial thermometers by $M$. Tonnelot; an air thermometer by M. Golaz; a spherometer by M. Brunner; and other measuring instruments by MM. Oertling, Boudin, Alvergniat, Simmen, and the Société Genevoise.

In the fourth volume of the Travaux et Miemoires of the Bureau (Paris, Gauthier-Villars, I885) reference was made by the Director of the Bureau to the work then in progress, and in the present Report a summary is given of the whole work done by the Committee during the past twelve months.

The work of the Director has specially included the verification of the lengths and coefficients of expansion of several standard metres, and the determination of the weights and specific gravities of several standard kilogrammes for different Governments and scientific authorities. A report is given on the comparison of the new kilogramme prototype (K. III.) with the old kilogramme des Archives, and also on the verification at Paris, by Dr. J. Broch and Mr. H. J. Chaney, of certain British standards. During the present year the Committee report that Dr. Broch will continue his researches on the influence of light on the defining-lines of standards of length, and M. Benoit will also carry on his experiments on the best means of comparing end-measures of length (mesures à bouts) with line-measures (mesures $a$ traits). Dr. Thiesen will continue his interesting studies on balances and the verification of kilogramme standards.
Dr. Chappuis, with the assistance of Dr. Guillaume, will also continue the experiments on the verification of thermometers:

It wou:d appear that the Committee are carrying out the duties intrusted to them with all possible care and despatch. In the preparation of the alloy of platinumiridium, of which the standards of the kilogramme and metre are made, extraordinary difficulties were originally encountered, owing mainly to the presence in the iridium of iron, rhodium, ruthenium, osmium, and other metals, and the Committee therefore obtained the assistance of MM. Stas and Debray. The report of these eminent metallurgists shows that the Committee are indebted to Mr. G. Matthey for the production of an alloy having the high purity and finish required for such work.

The Report of the Committee includes copies of its correspondence with the different contracting Governments. In an able note to the Japanese Minister, Dr A. Hirsch (the Secretary of the International Committee) explains the objects of the Metric Bureau, and it is gratifying to find that Japan has now joined the Convention. From the correspondence with this country it would appear that our Government will in due course obtain copies of the new metric standards.

The Committee announce that the vacancies caused by the death of Prof. Heer and the resignations of Gen. Wrede and Dr. Gould have been filled by the election by the Committee of Prof. Th. v. Oppolzer, Mr. W. H. M. Christie, and Prof. Thalèn.

The Report also includes copies of a correspondence with reference to a proposal made by the French Government to extend the functions of the Bureau to the determination and verification of electrical standards of resistance and light, for the use of the different Governments. The proposal appears to have gone no farther at present than asking the several contracting Governments whether they would have objection to the preparation of estimates showing the cost of a new or extended Bureau for electrical purposes. The replies of Belgium, Denmark, Spain, the United States, Italy, Servia, and Switzerland are attached, but, excepting Spain and Switzerland, it cannot be said that generally the Governments appear to bave given the proposal the most cordial welcome.

\section{THE WEATHER OF THE ICE SAINTS FESTIVALS OF 1886}

AST year we chronicled (NATURE, vol, xxxii. p. 62) one of the most disastrous snowstorms that ever occurred at this season in Vienna, where, on May I5, there fell $5 \frac{1}{2}$ inches of snow, and the cold accompanying the storm was so intense that several persons who were exposed to it were frozen to death. Over Austria and Hungary snow covered the fields and vineyards, and, the crops being in a somewhat advanced condition at the time, an incalculable amount of damage was done. But the festivals of the Ice Saints (May I i, 12 , and 13 ) this year have been marked off for a wider and deeper remembrance by storms of wind, rain, hail, and snow in all the continents of the northern hemisphere, which, for number and destructiveness, are perhaps unexampled at this time of the year.

In the British Islands the cold acquired its greatest intensity on the five days from May II to 15 , and was coincident with a system of pressures which appeared in the Channel, and thence proceeded in a north-northeasterly direction through the North Sea to the southwest of Norway, which was reached on the I5th. It necessarily resulted from this distribution of pressure that northerly and easterly winds prevailed in these islands, and temperature fell correspondingly low. Over that 